\title{
THE GROWING TECHNOLOGY OF MIXED SEEDED PLANTS AT STUBBLE-FIELD
}

\author{
ALLAHVERDIYEV Elkhan Rajab, Azerbaijan State Agrarian University \\ MAMEDOVA Aytekin Sabir, Azerbaijan State Agrarian University
}

\begin{abstract}
One of the main measures to increase production in the field of grain and feed production in our republic is to increase the yield of grain and forage crops on plantations. The purpose of our research work is to study the effect of fertilization and irrigation rates on the yield, crop quality and soil fertility of crops sown in a mixture when planting honeysuckle. The results of research conducted in world agriculture show that mainly the yield and composition of mixed crops, the quality indicators of which depend on the components of the crops to be sown, their seeding rate and cultivation technology. As a result of studies conducted in the conditions of ancient irrigated gray-meadow soils of the Karabakh region of our republic, it was found that with 4 -fold vegetation irrigation (4200 $\left.\mathrm{m}^{3}\right)$, the yield of mixed sowing in the control version without fertilizers was $372 \mathrm{c} / \mathrm{ha}$, while under the influence of mineral and organic mineral fertilizers, the yield increased and amounted to 447-627 c/ha. Based on the results of the study, it can be said that in order to obtain a high yield of green mass with the joint sowing of corn and soybeans, the optimal irrigation and fertilizer application rates were determined, the highest indicator was achieved in the variant where the fertilizer standards N120P150C150 were applied. In the course of the study, the influence of fertilizer application rates and optimization of the amount of irrigation on the quality indicators of feed, as well as on the yield obtained from mixed crops, was studied. As a result of the conducted analyses, the amount of raw protein, absolute dry matter, nitrate nitrogen in the natural mass, the yield of feed units per hectare and the amount of protein going for digestion were determined. Thus, the application of fertilizers within the optimal limits and the correct, timely supply of irrigation standards significantly increase the quality of the crop on a par with the yield on mixed crops, the soil fertility is preserved.
\end{abstract}

The presentation and problem of research. It is possible to increase the productivity and yield quality and save the soil fertility of fodder crops and also to get two yields in a year from stubble-fields.

The researchers conducted during many years shows that in stubble-fields there will be collected many proteins and it will causes the high quality of fodder in stubble-field comparatively to autumn and spring cropping.

No other matter can substitute protein in human and animal foods. As a result of the deficiency of proteins in feeding of animals the productivity of them decreases. So that, the deficiency of proteins in foods causing a serious breach of metabolism. In addition to cereal crops, cereals and leguminous plants have an important role in raising protein reserves. There's a particularly great importance of the high content of protein in plant $[1,7]$.

The important aims set forward after conducted soil reforms in our republic are the cultivation of crops in scientifically bases, the increasing of soil fertility by complying with agrotechnical measures, as well as getting two yields in a year by the proper sorting of the different cereals. The limit of sowed lands in our republic makes necessary to get two yields in a year and there's a favorable soil-climatic condition in the region for this. It is important to choose soon ripening varieties of cereals and leguminous plants, work out and investigate progressive cultivation technologies in order to save water-physic qualities, balance of nutrients and soil fertility for getting two yields in one year by maximum usage of soil and solar energy. This caused rational using of sown areas, increasing fodder production and developing of this branch [20].

Leguminous plants riches the soil with nitrogen, improves soil structure and its' water-physician property. Many researches showed that in the case of extending the norms of nitrogen fertilizers influences the growth of maize but weakens the development of leguminous plants [18].

The researches defined that in the case of increasing norms of nitrogen fertilizers it positively influence to maize productivity and quality but this weakens the development of soybean because there forms few root bacteria in the root [15].

When providing maize with nitrogen and phosphorus fertilizers it accelerates plants' growth and development and increases proteins in yield [16].

The normal nutrition of agricultural crops has a substantial impact to their growth, development and productivity. There were discovered more than 70 elements in plants' composition. Though most elements takes part in nutrition of plants only small amount of them accesses it in such a few quantity that it can be defined with difficulty, even there is an element that cannot be defined.

By taking into consideration the biological properties of mixed cropped plants it is possible to regulate nutrition level of plants, to raise considerably the productivity and yield quality by properly adhering the correct proportion of nutrition elements in fertilizers. In the case of nutrition plants with nutrition elements in optimal norms it increases the synthesis of protein matters and enhances the life activity of plant, it continues for a long time, accelerates plant's growth, slows the aging of leaves a bit. It should be noted that excessively nutrition of plants by nutrition elements mainly by nitrogen sometimes slows down plant's maturity.

The results of conducted researches in the world agriculture shows that mainly the productivity and 
composition, the qualitative indicators of mixed cropped plants depends on the components of plants, their norms of sowing and cultivation technology.

Therefore, it is more beneficial to plant singleyear leguminous plants in the main and intermediate fields of mixed-planted crops with cereals. It is possible to obtain crops twice a year from the same sown area at the expense of such mixed sprouting. The greatest importance of such sowing is that extra territories are not required during planting. This is one of the main requirements of the modern era. Because of the limited availability of land plots currently in operation, the farmers are effectively using it, getting high yields without increasing the field and working on the principle of harvesting twice a year from the same planting sites [4].

In order to improve the absorption of organic and mineral fertilizers for mixed sprouts, $50-70$ p.c. of phosphorus, $100 \%$ of potassium and organic fertilizers, and some of the remainder of the phosphorus to the seeds in order to provide the plant with nutrients, the rest should be given at the last feeding. Fertilizer increases the vegetation duration, height, age and dry matter of the plant, significantly improves the product's structural characteristics. Fertilizers can increase maize productivity by 30-40 p.c. or more. The combination of organic and mineral fertilizers in the optimum norm allows increasing the productivity and quality of the green mass of mixed plants [5].

Optimal fertilizer norms and rates have been established to ensure the productivity of corn-soybean crops in the foothills of the southern-eastern zone of Kazakhstan and the increase in protein content in the feed mass [10].

S. J. Bekbolatov shows in his researches that by the influence the fertilizers in optimal norm of $\mathrm{N}_{90} \mathrm{P}_{120} \mathrm{~K}_{120}$ and in the norm of using 20 tons of manure/hectare + $+\mathrm{N}_{30} \mathrm{P}_{90} \mathrm{~K}_{90}$ the silage masses productivity of the maizesoybean mixture was 660-690 centners/hectare, fodder unit 168-188 centners/hectare, and the digested protein - 17-18 centners/hectare. However, the amount of protein digested in the silo mass is estimated to be in line with the physiological norms required for the feeding of agricultural animals [9].

One of the important agro-technical measures used to obtain high yields from mixed cultivars is the study of the required amount of nutritional content on a scientific basis. Therefore, the effective use of organic and mineral fertilizers plays a major role in obtaining high yields from mixed crops. Organic and mineral fertilizer norms have been studied, taking into account the biological characteristics of cultivated plants and the extent to which they are provided with nutrients in the soil [13].

Material and methods. The effect of fertilizer norms and irrigation on corn and soybeans productivity was as shown in table 1.

The conducted studies prove that proper selection of plants in mixed sprouting, implementation of complex agrotechnical measures, application of mineral and organic and mineral fertilizers considerably increases the quantity and quality of gross product.

As can be seen in Table 1, the use of groundwater and organic mineral fertilizers in practice has shown a positive impact on the yield of corn and soybean crops in mixed crops.

As a result of our research, it has been established that on the basis of 4 times vegetable irrigation $\left(4200 \mathrm{~m}^{3}\right)$ in the control variant without using fertilizer while the productivity of mixed crops was 372 centner/hectare, it increased and varied from 447 to 627 centner/hectare with the use of mineral and organic fertilizers.

Thus, as a result of the research, it can be seen that the productivity of soybean and soybean crops can be significantly increased by applying mineral and organic mineral fertilizers on the basis of 4 times vegetation irrigation $\left(4,200 \mathrm{~m}^{3} / \mathrm{ha}\right)$ when irrigation water is scarce. So that, while the productivity of mixed crops was 372 centner/hectare in the variant of introduction the

Table 1

The influence of fertilizer and irrigation norms to productivity of mixed cropping of maize and soybean

\begin{tabular}{|c|c|c|c|c|c|c|c|}
\hline \multirow{3}{*}{ № } & \multirow{3}{*}{ Variants } & \multicolumn{3}{|c|}{4 time irrigation $\left(4200 \mathrm{~m}^{3}\right)$} & \multicolumn{3}{|c|}{6 time irrigation $\left(6300 \mathrm{~m}^{3}\right)$} \\
\hline & & \multirow{2}{*}{$\begin{array}{c}\text { Average } \\
\text { productivity, } \\
\text { cent/ha }\end{array}$} & \multicolumn{2}{|c|}{ Increase } & \multirow{2}{*}{$\begin{array}{c}\text { Average } \\
\text { productivity, } \\
\text { cent/ha }\end{array}$} & \multicolumn{2}{|c|}{ Increase } \\
\hline & & & cent/hec & p.c. & & cent/hec & p.c. \\
\hline I & Control (without fertilizer) & 372 & - & - & 392 & - & - \\
\hline II & $\mathrm{N}_{40} \mathrm{P}_{60} \mathrm{~K}_{60}$ & 465 & 93 & 25,00 & 490 & 98 & 25,00 \\
\hline III & $\mathrm{N}_{60} \mathrm{P}_{90} \mathrm{~K}_{90}$ & 521 & 149 & 40,05 & 572 & 180 & 45,91 \\
\hline IV & $\mathrm{N}_{90} \mathrm{P}_{120} \mathrm{~K}_{120}$ & 618 & 246 & 66,12 & 668 & 276 & 70,40 \\
\hline $\mathrm{V}$ & $\mathrm{N}_{120} \mathrm{P}_{150} \mathrm{~K}_{150}$ & 633 & 261 & 70,16 & 684 & 292 & 74,48 \\
\hline VI & Manure $10 \mathrm{t} /$ hec $+\mathrm{P}_{35}$ & 447 & 75 & 20,16 & 469 & 77 & 19,64 \\
\hline VII & Manure $10 \mathrm{t} / \mathrm{hec}+\mathrm{N}_{10} \mathrm{P}_{65} \mathrm{~K}_{30}$ & 567 & 195 & 52,41 & 589 & 197 & 50,25 \\
\hline VIII & Manure $10 \mathrm{t} / \mathrm{hec}+\mathrm{N}_{40} \mathrm{P}_{95} \mathrm{~K}_{60}$ & 591 & 219 & 58,87 & 629 & 237 & 60,45 \\
\hline IX & Manure $10 \mathrm{t} / \mathrm{hec}+\mathrm{N}_{70} \mathrm{P}_{125} \mathrm{~K}_{90}$ & 600 & 228 & 61,29 & 645 & 253 & 64,54 \\
\hline
\end{tabular}


norm of $\mathrm{N}_{40} \mathrm{P}_{60} \mathrm{~K}_{60}$ it became 473 centner/hectare, in the variant of introduction the norm of $\mathrm{N}_{60} \mathrm{P}_{90} \mathrm{~K}_{90}$ it became 604 centner/hectare, in the variant of introduction the norm of $\mathrm{N}_{90} \mathrm{P}_{120} \mathrm{~K}_{120}$ it became 618 centner/hectare, in the variant of introduction the norm of $\mathrm{N}_{120} \mathrm{P}_{150} \mathrm{~K}_{150}$ it became 627 centner/hectare that shows the increase of 255 centner/hectare or 68 p.c. relatively to control variant. Mineral and organic mineral fertilizers also seemed to have increased productivity. So that there were obtained 447 centner/hectare of the green mass yield in the variant of introduction 10 tons of manure $10 \mathrm{t} / \mathrm{hec}+\mathrm{P}_{35}, 572$ centner/hectare of the green mass yield in the variant of introduction 10 tons of manure $10 \mathrm{t} / \mathrm{hec}+\mathrm{N}_{10} \mathrm{P}_{65} \mathrm{~K}_{30}, 584$ centner/hectare of the green mass yield in the variant of introduction 10 tons of manure/hectare $+\mathrm{N}_{40} \mathrm{P}_{95} \mathrm{~K}_{60}$ and 597 centner/hectare of the green mass yield in the variant of introduction 10 tons of manure/hectare $+\mathrm{N}_{70} \mathrm{P}_{125} \mathrm{~K}_{90}$. And this means the increase of 225 centner/hectare or 60 p.c. relatively to control variant.

While the productivity was 399 centner/hectare in the control variant on the base of 6 time irrigation it changed from 475 centner/hectare to 681 centner/ hectare by using mineral and organic fertilizers.

On the base of 6 time irrigation $\left(6300 \mathrm{~m}^{3} / \mathrm{hec}\right)$ it is expected to be the same thing. So that in the variant of introduction fertilizers at the norm of $\mathrm{N}_{40} \mathrm{P}_{60} \mathrm{~K}_{60}$ it was obtained the yield of $503 \mathrm{cent} / \mathrm{hec}$, at the norm of $\mathrm{N}_{60} \mathrm{P}_{90} \mathrm{~K}_{90}$ it was obtained the yield of 636 cent/hec, at the norm of $\mathrm{N}_{90} \mathrm{P}_{120} \mathrm{~K}_{120}$ it was obtained the yield of 667 cent/hec, at the norm of $\mathrm{N}_{120} \mathrm{P}_{150} \mathrm{~K}_{150}$ it was obtained the yield of $681 \mathrm{cent} / \mathrm{hec}$, and it shows the increase of 282 cent/hec or $70 \%$ on comparison to the control variant.

It turned out that the productivity had also increased on the base of 6 time irrigation $\left(6300 \mathrm{~m}^{3} / \mathrm{hec}\right)$ and introduction mineral and organic fertilizers. So that in the case of introduction manure $10 \mathrm{t} / \mathrm{hec}+$ $+\mathrm{P}_{35}$ there was obtained the green mass yield of 475 cent/hec, manure $10 \mathrm{t} / \mathrm{hec}+\mathrm{N}_{10} \mathrm{P}_{65} \mathrm{~K}_{30}-$ 594 cent/hec, manure $10 \mathrm{t} / \mathrm{hec}+\mathrm{N}_{40} \mathrm{P}_{95} \mathrm{~K}_{60}-$ 633 cent/hec, manure $10 \mathrm{t} / \mathrm{hec}+\mathrm{N}_{70} \mathrm{P}_{125} \mathrm{~K}_{90}-$ 647 cent/hec. And it shows the increase of 248 cent/hec or 62 p.c. on comparison to the control variant.

However, it should be noted that irrigation water is low in our country, mainly in the Aran region. So when purchasing 6 irrigation here, the product is not economically viable.

The mathematical calculations at the end of the study prove the accuracy of the experiment.

Based on the findings of the study, we can say that optimal irrigation and fertilizer norms have been identified in order to obtain high green mass during the mixed cropping of corn and soybean.

The researches of many specialists shows that for increasing fodder quality of maize and sorghum it is necessary to sow their biocenosis by plants with high protein especially with soybean, pea, bean and so on. We know that the structure of biocenosis defines the productivity of the plant and the quality of yield.

It has been revealed that one-year leguminous plants are richer in proteins than cereals 1.5-2 times, and significantly increases the amount of raw protein in feed as a mixed crop component. The value of leguminous plants is to enrich the soil with nitrogen by detecting the atmospheric nitrogen $[2,14]$.

During the study, there was also studied the effect of mineral and organic fertilizer norms and optimization of number of irrigation both to the productivity and obtained fodder's quality. As a result of the analysis, the amount of raw protein, absolute dry matter, nitrate nitrogen in the natural mass, fodder unit coming out of the hectare and the amount of the digestion protein were determined. The results of the analysis are shown in table 2 .

As can be seen in table 2, on the base of 4 time irrigation on the stubble-field while the raw protein was $6,0-6,2$ p.c. at the control variant without using fertilizer by growing the mixed cropping of maize and soybean, at the variant of introduction $\mathrm{N}_{40} \mathrm{P}_{60} \mathrm{~K}_{60}$ it became 6,4-6,5 p.c., at the variant of introduction N60P90K90 - 6,5-6,7 p.c., $\mathrm{N}_{90} \mathrm{P}_{120} \mathrm{~K}_{120}-$ 6,9-7,1 p.c., $\mathrm{N}_{120} \mathrm{P}_{150} \mathrm{~K}_{150}-7,1-7,3$ p.c.

On the base of 4 times irrigation at the variants of using mineral and organic fertilizers together a simi-

The influence of norms of fertilizers and irrigations to the quality of yield at the mixed cropped plants (maize and soybean) in the stubble-fields

\begin{tabular}{|c|c|c|c|c|c|c|c|c|c|c|c|}
\hline \multirow{3}{*}{$\begin{array}{c}\text { № } \\
\text { I }\end{array}$} & \multirow{3}{*}{$\begin{array}{l}\text { Variants } \\
\text { without fertilizer) }\end{array}$} & \multirow{2}{*}{\multicolumn{2}{|c|}{$\begin{array}{l}\text { Raw protein } \\
\text { in dry matter, p.c. }\end{array}$}} & \multirow{2}{*}{\multicolumn{2}{|c|}{$\begin{array}{l}\text { Absolute dry } \\
\text { matter, p.c. }\end{array}$}} & \multirow{2}{*}{\multicolumn{2}{|c|}{$\begin{array}{l}\text { The nitrate } \\
\text { nitrogen in natural } \\
\text { mass, mg'kg }\end{array}$}} & \multicolumn{4}{|c|}{ From one hectare } \\
\hline & & & & & & & & \multicolumn{2}{|c|}{$\begin{array}{c}\text { Fodder unit } \\
\text { output }\end{array}$} & \multicolumn{2}{|c|}{$\begin{array}{c}\text { Digested } \\
\text { protein, kg }\end{array}$} \\
\hline & & 6,0 & 6,2 & 23,0 & 23,5 & 65 & 71 & 8057 & 8642 & 718,1 & 770,2 \\
\hline II & $\mathrm{N}_{40} \mathrm{P}_{60} \mathrm{~K}_{60}$ & 6,4 & 6,5 & 24,0 & 24,5 & 69 & 77 & 10245 & 10895 & 913,1 & 971,0 \\
\hline III & $\mathrm{N}_{60} \mathrm{P}_{90} \mathrm{~K}_{90}$ & 6,6 & 6,7 & 24,4 & 25.0 & 73 & 82 & 13082 & 13775 & 1166,0 & 1227,8 \\
\hline IV & $\mathrm{N}_{90} \mathrm{P}_{120} \mathrm{~K}_{120}$ & 6,9 & 7,1 & 25,0 & 26,0 & 78 & 87 & 13386 & 14447 & 1190,0 & 1287,6 \\
\hline $\mathrm{V}$ & $\mathrm{N}_{120} \mathrm{P}_{150} \mathrm{~K}_{150}$ & 7,1 & 7,3 & 26,0 & 26,5 & 85 & 92 & 13580 & 14750 & 1210,4 & 1314,6 \\
\hline VI & Manure $10 \mathrm{t} / \mathrm{hec}+\mathrm{P}_{35}$ & 6,4 & 6,6 & 23,5 & 24,0 & 68 & 77 & 9682 & 10288 & 862,9 & 916,9 \\
\hline VII & Manure $10 \mathrm{t} / \mathrm{hec}+\mathrm{N}_{10} \mathrm{P}_{65} \mathrm{~K}_{30}$ & 6,6 & 6,7 & 24,0 & 25,5 & 73 & 79 & 12389 & 12866 & 1104,2 & 1146,7 \\
\hline VIII & Manure $10 \mathrm{t} / \mathrm{hec}+\mathrm{N}_{40} \mathrm{P}_{95} \mathrm{~K}_{60}$ & 7,0 & 7,1 & 24,5 & 26,0 & 78 & 85 & 12649 & 13711 & 1127,4 & 1221,9 \\
\hline IX & Manure $10 \mathrm{t} / \mathrm{hec}+\mathrm{N}_{70} \mathrm{P}_{125} \mathrm{~K}_{90}$ & 7,2 & 7,2 & 26,0 & 26,5 & 86 & 91 & 12931 & 14014 & 1152,5 & 1249,0 \\
\hline
\end{tabular}


lar case has occurred. So that in the case of introduction Manure $10 \mathrm{t} / \mathrm{hec}+\mathrm{P}_{35}$ the raw protein was 6,4-6,6 p.c., manure $10 \mathrm{t} / \mathrm{hec}+\mathrm{N}_{10} \mathrm{P}_{65} \mathrm{~K}_{30}-6,6-$ 6,7 p.c., manure $10 \mathrm{t} / \mathrm{hec}+\mathrm{N}_{40} \mathrm{P}_{95} \mathrm{~K}_{60}-7,0-7,1$ p.c., manure $10 \mathrm{t} / \mathrm{hec}+\mathrm{N}_{70} \mathrm{P}_{125} \mathrm{~K}_{90}-7,2$ p.c.

From the results of the analysis, it is clear that the amount of dry substance in absolute dry weight has increased significantly due to fertilizer and irrigation norms. For example, while the amount of dry matter was $23,0-23,5$ p.c., it has increased to $24-24,5$ p.c. at the variant of introduction $\mathrm{N}_{40} \mathrm{P}_{60} \mathrm{~K}_{60}, 24,4-25,0 \%$ - at the variant of introduction $\mathrm{N}_{60} \mathrm{P}_{90} \mathrm{~K}_{90}, 25,0-26,0$ p.c. at $\mathrm{N}_{90} \mathrm{P}_{120} \mathrm{~K}_{120}$ and $26,0-26,5$ p.c. - at $\mathrm{N}_{120} \mathrm{P}_{150} \mathrm{~K}_{150}$.

An analogous situation has occurred at the variants of introduction mineral and organic fertilizers together. So that in the case of introduction Manure $10 \mathrm{t} / \mathrm{hec}+\mathrm{P}_{35}$ the raw protein was 23,5-24,0 p.c., manure $10 \mathrm{t} /$ hec $+\mathrm{N}_{10} \mathrm{P}_{65} \mathrm{~K}_{30}-24,5-25,5$ p.c., manure $10 \mathrm{t} / \mathrm{hec}+\mathrm{N}_{40} \mathrm{P}_{95} \mathrm{~K}_{60}-24,5-26,0$ p.c., manure $10 \mathrm{t} / \mathrm{hec}+\mathrm{N}_{70} \mathrm{P}_{125} \mathrm{~K}_{90}-26,0-26,5$ p.c.

In practice, the effect of fertilizers on the amount of nitrates collected in green feed has been determined. The results of the analysis show that mineral and organic fertilizers increase nitrate nitrogen in green feed. So that while the nitrate is concentrated in natural mass in $65-1 \mathrm{mg} / \mathrm{kg}$ at the area of without using fertilizer, this indicator has increased to $69-77 \mathrm{mg} / \mathrm{kg}$ at the variant of introduction N40P60K60, to $73-82 \mathrm{mg} / \mathrm{kg}$ at the variant of introduction $\mathrm{N}_{60} \mathrm{P}_{90} \mathrm{~K}_{90}$, to $78-87 \mathrm{mg} / \mathrm{kg}$ at the variant of introduction $\mathrm{N}_{90} \mathrm{P}_{120} \mathrm{~K}_{120}$ and to $85-92 \mathrm{mg} / \mathrm{kg}$ at the variant of introduction $\mathrm{N}_{120} \mathrm{P}_{150} \mathrm{~K}_{150}$.

An analogous situation has occurred at the variants of introduction mineral and organic fertilizers together. So that in the case of introduction Manure $10 \mathrm{t} / \mathrm{hec}+$ $+\mathrm{P}_{35}$ the raw protein was $68-77 \mathrm{mg} / \mathrm{kg}$, manure $10 \mathrm{t} / \mathrm{hec}+\mathrm{N}_{10} \mathrm{P}_{65} \mathrm{~K}_{30}-73-79 \mathrm{mg} / \mathrm{kg}$, manure $10 \mathrm{t} / \mathrm{hec}+$ $+\mathrm{N}_{40} \mathrm{P}_{95} \mathrm{~K}_{60}-78-85 \mathrm{mg} / \mathrm{kg}$, manure $10 \mathrm{t} / \mathrm{hec}+$ $+\mathrm{N}_{70} \mathrm{P}_{125} \mathrm{~K}_{90}-86-91$. These indicators were significantly lower than the maximum permissible concentration in feed plants ( $200 \mathrm{mg} / \mathrm{kg}$ in natural mass). This proves that the produced product is ecologically clean.

During the study, the amount of fodder output and the amount of digested protein were studied in the green mass from mixed plantings by introduction of mineral and organic-mineral fertilizers. While at the control variant without using fertilizers the fodder output from 1 hectare and was 8057 and the digested protein $718,1 \mathrm{~kg} / \mathrm{hec}$, at the variant of introduction $\mathrm{N}_{40} \mathrm{P}_{60} \mathrm{~K}_{60}$ these indicators became 10245 and $913,1 \mathrm{~kg} / \mathrm{hec}$, at the variant of introduction $\mathrm{N}_{60} \mathrm{P}_{90} \mathrm{~K}_{90}-13082$ and $1166,0 \mathrm{~kg} / \mathrm{hec}$, at the variant of introduction $\mathrm{N}_{90} \mathrm{P}_{120} \mathrm{~K}_{120}-13386$ and $1190,0 \mathrm{~kg} / \mathrm{hec}$, at the variant of introduction $\mathrm{N}_{120} \mathrm{P}_{150} \mathrm{~K}_{150}-13580$ and $1210,4 \mathrm{~kg} / \mathrm{hec}$.

An analogous situation has occurred at the variants of introduction mineral and organic fertilizers together. So that at the variant of manure $10 \mathrm{t} / \mathrm{hec}+\mathrm{P}_{35}$ the fodder output from 1 hectare and was 9682 and the digested protein $862,9 \mathrm{~kg} / \mathrm{hec}$, at the variant of introduction manure $10 \mathrm{t} / \mathrm{hec}+\mathrm{N}_{10} \mathrm{P}_{65} \mathrm{~K}_{30}$ these indicators became 12389 and $1104,2 \mathrm{~kg} / \mathrm{hec}$, at the variant of in- troduction manure $10 \mathrm{t} / \mathrm{hec}+\mathrm{N}_{40} \mathrm{P}_{95} \mathrm{~K}_{60}-12649$ and $1127,4 \mathrm{~kg} / \mathrm{hec}$, at the variant of introduction manure $10 \mathrm{t} / \mathrm{hec}+\mathrm{N}_{70} \mathrm{P}_{125} \mathrm{~K}_{90}-12931$ and $1152,5 \mathrm{~kg} / \mathrm{hec}$.

Thus, the introduction of fertilizers and in optimal limit proper and timely delivery of irrigation norms substantially increases the productivity and yield quality in mixed cropping.

Simple and inexpensive way to recover soil fertility is to use leguminous plants. Leguminous plants enrich the soil with biological nitrogen and root mass, which improves the ecological condition of the soil and shows that it is more important for economic efficiency. As a result of the symbiotic activity of pulsed bacteria in leguminous plants, it is mined and absorbed into the metabolite, absorbing the inevitable molecular nitrogen of the atmosphere [3].

When maize and soybean are grown together, the root and surface mass increases more significantly of the fertilizer and irrigation norms and numbers. This is explained by the fact that soybeans collect nitrogen in the soil and provide maize partially with nitrogen [11].

The amount of nutrition elements contained in the soil by roots and stubbles is related to the amount of plant residues and their nutritional elements. In addition to the nutrient elements contained by the root mass of the plants and the fragile residues of the soil, they also contain a large amount of carbon dioxide, it causes the creation of favorable conditions for the more efficient nutrition of plants, which in turn increases the productivity of the plants and the quality of the product [6].

In the research conducted at the low part of Karabakh region there were taken roots and stubble remains from mixed cropping of maize and soybean by monolith method, dried at open air, common nitrogen, phosphorus and potassium were defined. As a result of the analysis, it was found that the total amount of nitrogen, phosphorus and potassium in the composition of the root and stubble residues significantly varies depending on the number of irrigation and fertilizer norms.

Generally speaking, the application of mineral and organic fertilizers to the optimum norms significantly increases soil fertility by quantitative and qualitatively effecting residues to the root mass of mixed slaughters. This proves that soybean corn and soybean are a good predetermine for plants that come after themselves.

Giving the organic and mineral fertilizers to soil on the scientific basic right norm with agrotechnical care doesn't only allow soils to decrease, but also with providing the increasing of soil fertility provides increasing of quantitative and qualitative indicators of green mass yield and plants' growth and development.

Result of the research. The following results have been achieved in the research.

1. For rational using of soil, favorable climatic condition and other factors in order to provide livestock's demand to fodder and to increase fodder production it is advisable to cultivate stubble-fields.

2. Optimum fertilizer and irrigation rates should be applied in order to maintain soil fertility along with increasing productivity. 
3. Highest indicators in the research have been obtained in the variant of introduction $\mathrm{N}_{120} \mathrm{P}_{150} \mathrm{~K}_{150}$.

4. At the variant of introduction $\mathrm{N}_{120} \mathrm{P}_{150} \mathrm{~K}_{150}$ the were obtained the highest indicators.

\section{REFERENCES}

1. Allahverdiyev E.R. Impact of new sowing technology on yield and soil fertility in the joint planting of corn and soybean / Ganja regional scientific center of ANAS. Ganja, 2005, P. 71-73.

2. Allahverdiyev E.R., Jafarov F. The importance of mixed planting. Modern Agrarian Science: Actual Problems and Development Prospects in the Globalization Condition // International Scientific-Practical Conference. I volume, Ganja, 2014, p. 145-146.

3. Allahverdiyev E.R., Hasanova O., Aliyeva S.F. Role of cultivated seedlings in efficient use of soil // Materials of the republican scientific conference on integration and modern problems of science in the modern world Lankaran State University, 22-23 December 2017, P. 209-210.

4. Aliyev Ch.S., Kazimov Q.A. Importance of turnover crop rotation in irrigation conditions // AzETEI's scientific works collection, Baku 2012, P. 223-225.

5. Gurbanov F.H. Role of fertilizers in increase of productivity of corn type ASAU-80 // Soil science and agrochemistry, 2013, Vol. 3, P. 267-268.

6. Mammadov G.Y, Khudiyev A.P., Huseynov A.R. Determination of the poorness of corn seeds and ways to increase the fodder value // Ganja RSC of AzNSA, 2011, No. 46, P. 104-107.

7. Sattarov S.X. and others. Establishment of a solid feed base in the Republic of Azerbaijan. Baku, "Chashıglu" 2001, 155 p.

8. Akman Z., Sencar O. Effect of different sowing systems on yield and some agronomic properties in the production of corn-legumes (bean and cowpea) together? Turk J Agric For, 1999, No. 23 (5), P. 1139-1148.

9. Gerasenkov V.I., Soboleva N.V. Cultivation of corn for silage in a mixture with annual legumes // Reports of the Academy of Agricultural Sciences, Moscow, 1972, P. 9-11.
10. Kozyr B.C., Zaporozhchenko A.L. Mixed crops of maize with mallow // Fodder production, 1986, No. 2, P. 33-35.

11. Korzun O.S. Biochemical composition of green mass of millet and prosovidnyh crops depending on the doses of mineral fertilizers / Forage production: technology, economics, soil conservation. - Sat. mat. MNPK RUE "NPCNANB on agriculture". - Mn .: IVC of the Ministry of Finance, 2009, P. 175.

12. Popov P.D., Sokolov A.V., Zamana S.P. Prospects for increasing the productivity of fodder lands // Arable farming. 2002, No. 1, P. 22-23.

13. Sadokhina T.A., Bakshayev D.U. Mixed crops of cereals and fodder beans for use in grain mill // Siberian Herald of Agricultural Science, 2015, P. 57-62.

14. Borodoev V.V., Kostyakova A.N., Pimokov K.I. Agrochemical evaluation of the application of mineral fertilizers and biopreparations in the cultivation of chick pea in the Rostov region // Fertility, 2018, No. 1 (100), P. 34-37.

15. Ali A., Ijoyah M.O. and Usman M. Intercropped maize and soybean under tillage practices and fertilizer rates in Makurdi, Southern Guinea Savanna Zone of Nigeria // International Journal of Novel Research in Civil Structra land Earth Sciences, 2015, No. 2(2), P. 12-20.

16. Yang S., Li F., Malhi S.S., Wang P., Suo D., Wang J. Long-term fertilization effects on crop yield and nitrate nitrogen accumulation in soil in Northwestern China // Agronomy Journal; Madison, 2004, Vol. 96, No.4, P. 1039-1049.

Allahverdiyev Elkhan Rajab, Candidate of Agricultural Sciences, Associate Professor, Azerbaijan State Agrarian University. Azerbaijan Republic.

Mamedova Aytekin Sabir, Candidate of Agricultural Sciences, Associate Professor, Azerbaijan State Agrarian University. Azerbaijan Republic.

Azerbaijan Republic Ganja, N. Narimanova Ave, building 22 fl. 31.

E-mail: elxan_recebli@mail.ru cell:0506687678.

Keywords: Bucket; planting; mixture; sowing; fertilizer; norm; watering; yield; quality; soil; fertility.

\section{ТЕХНОЛОГИЯ ВЫРАЩИВАНИЯ СМЕШАННЫХ ПОСЕВНЫХ РАСТЕНИЙ НА СТЕРНЕ}

Аллахвердиев Эльхан Раджаб, канд. с-х. наук, доцент, Азербайджанский государственный аграрный университет.

Мамедова Айтекин Сабир, канд. с-х. наук, доцент, Азербайджанский государственный аграрный университет.

Ключевые слова: ковшан; посадка; смесь; посев; удобрение; норма, полив; урожайность; качество; почва; плодородие.

Одной из основных мер увеличения производства зерна и кормов в республике является повышение урожайности зерновых и кормовых культур на плантациях. Целью нашей исследовательской работы является изучение влияния внесения удобрений и норм полива на урожайность, качество урожая и плодородие почвы культур, посеянных в смеси при посадке жимолости. Результаты исследований, проведенных в мировом сельском хозяйстве, показывают, что в основном урожайность и состав смешанных культур, их качественные показатели зависят от компонентов высеваемых культур, нормы их высева и технологии возделывания. В ходе исследований, проведенных в условиях древних орошаемых серо-луговых почв Карабахского региона республики, было уста- новлено, что при 4-кратном поливе растительности $\left(4200 \mathcal{M}^{3}\right)$ урожайность смешанного посева в контрольном варианте (без удобрений) составила 372 и/га.Подвлияниемминеральныхиорганоминеральных удобренийурожайностьувеличиласъ и составила 447$627 u / 2 a$. Исходя из полученных результатов исследования, можно сказать, что для получения высокого урожая зеленой массы при совместном посеве кукурузы и сои были определены оптимальные нормы полива и внесения удобрений. Наивысший показатель был достигнут в варианте, где применялись нормы удобрений $\mathrm{N}_{120} P_{150} C_{150}$. В ходе исследования было изучено влияние норм внесения удобрений и оптимизации количества полива на качественные показатели кормов, а также на урожайность смешанных культур. Было определено количество сырого белка, абсолютного сухого вещества, нитратного азота в естественной массе, урожайность кормовых единиц, с гектара и количество белка, идущего на переваривание. Таким образом, внесение удобрений в оптимальных пределах и правильная, своевременная подача норм полива значительно повышают с урожайность смешанных культур при сохраняется плодородия почвы. 